\title{
Wildlife Problems in India
}

\author{
Report from the IUCN Assembly
}

New Delhi was a very happy choice of meeting place for the Ioth General Assembly of IUCN (International Union for Conservation of Nature), held there in November 1969. Few countries in the world have such a remarkable and wide range of wildlife as India, and at the same time face such immense difficulties and problems in preserving it. The debates at an IUCN Assembly are, of course, much wider ranging than the wildlife problems of the host country, but there is no doubt that the presence of 300 conservationists from all over the world was a tremendous stimulus to Indian conservationists and made a considerable impact in government circles and among thoughtful Indian citizens. For this we have in great measure to thank Mrs Gandhi, who, despite serious political distractions at the time, came to perform the official opening of the Assembly. Her cogent and thoughtful address made clear her deep concern for India's wildlife and natural resources and her awareness of the serious depletion of both. She spoke of the need for a massive campaign to educate the people in the first principles of nature conservation: "We must teach them from their early schooldays to become planters and protectors of trees and to care for animals'. She left the impression that words would be translated into deeds. Other notable and effective speakers at the opening were the Minister of Tourism, who is also the new Chairman of the Indian Wildlife Board, Dr Karan Singh, and the Minister of Agriculture, Shri Jagiivan Ram.

\section{Domestic Stock in Sanctuaries}

India's greatest problem is her vast and still increasing population. In terms of wildlife conservation this means not only destruction of habitat, but also vast numbers of domestic livestock-cows, buffaloes, goats, sheep-which graze in nearly every sanctuary with often disastrous effects on the wildlife. One of the Assembly's final resolutions took up this vitally important point, requesting federal and state governments to take immediate steps to curb and, if possible, prohibit stockgrazing in wildlife reserves and national parks.

\section{Animal Paradise}

George Schaller and Noel Simon set the wildlife scene in India with a paper on the Endangered Large Mammals of South Asia. 'Reading the hunting accounts of a century ago one gets the impression that South Asia was an animal paradise comparable to East Africa'-tiger, leopard, clouded and snow leopards, lion and cheetah; three species of bear; in the swamps and forests three species of rhinoceros, wild buffalo, elephant and gaur; in the open woodlands sambar, axis, hog and swamp deer, with blackbuck, nilgai and Indian gazelle; in the Himalayas, wild sheep and goats, yak, takin and serow-these were but a few of the great variety. Numbers, too, were often spectacular, with swamp deer 
crowding the reed beds of the Indus and Ganges in herds of thousands, and herds of 10,000 blackbuck in the Punjab. Today, 'each species clings to a small vestige of its former range'. In most South Asian countries, some three-quarters of the original wildlife habitats had been destroyed, and with them the wildlife; the possible exception was Bhutan. Schaller and Simon suggested that three main factors were the cause: destruction or degradation of habitat; hunting by man, and competition from domestic stock.

The majority of South Asia's mammals are forest dwellers, and less than 20 per cent of India today retains its forest cover. Only seven out of 20 states or territories have achieved the Government's aim to retain 30 per cent of the land under forest. As late as the I6th century rhinos and buffaloes (which favour moist conditions) were to be found in areas of western India which today are desert or semi-desert, and 'the desiccation of land is undoubtedly due to misuse of the soil by man'. The removal of the forests was the result of the increasing human population-from 270 million to 500 million in the last 35 years alone. Until the 16th century hunting was the prerogative of the Moghul emperors and the nobility, and this did not affect the numbers of most wild species; with the advent of British rule hunting became the pastime of administrative officers and soldiers, who, although hunting heavily, also introduced game regulations and established sanctuaries. But independence swept away the controls, and this, coupled with plentiful firearms, 'ushered in a period of destruction almost comparable to the uninhibited slaughter on the American prairies in the I850s'. The wildlife could not stand the ceaseless poaching and crop 'protection', and within five years much of it had gone. Today the dicline continues in the wildlife-but not in the domestic stock. In India there are some 250 million cattle and domestic buffalo, and roo million goats and sheep, of which at least Io per cent graze exclusively in the forests (where most wildlife survives). Moreover, the domestic stock transmits diseases such as foot and mouth and rinderpest which are endemic. In 1968 rinderpest occurred in the Bandipur Sanctuary, noted for gaur, and by October not one gaur could be found; sambar and chital were also seriously affected.

\section{The Point of No Return}

Turning to individual wild species, the authors considered six to have reached the point of no return: Sumatran and Javan rhinos, hispid hare, cheetah, Malabar civet and the Sikkim stag. A much larger group they considered to be in danger of extinction. although there was a serious lack of information about many of them, notably the Punjab urial, the straight-horned markhor, the golden and Nilgiri langurs, and the liontailed macaque; other species which needed urgent study included the Baluchistan bear, only rarely sighted in recent years, the Indian wild ass, the great Indian rhino, the Manipur brow-antlered deer and the Asiatic buffalo. One ray of light they saw in the situation was the fact that most of South Asia's endangered species are represented in sanctuaries or national parks, which also preserve representative habitats. Unfor- 


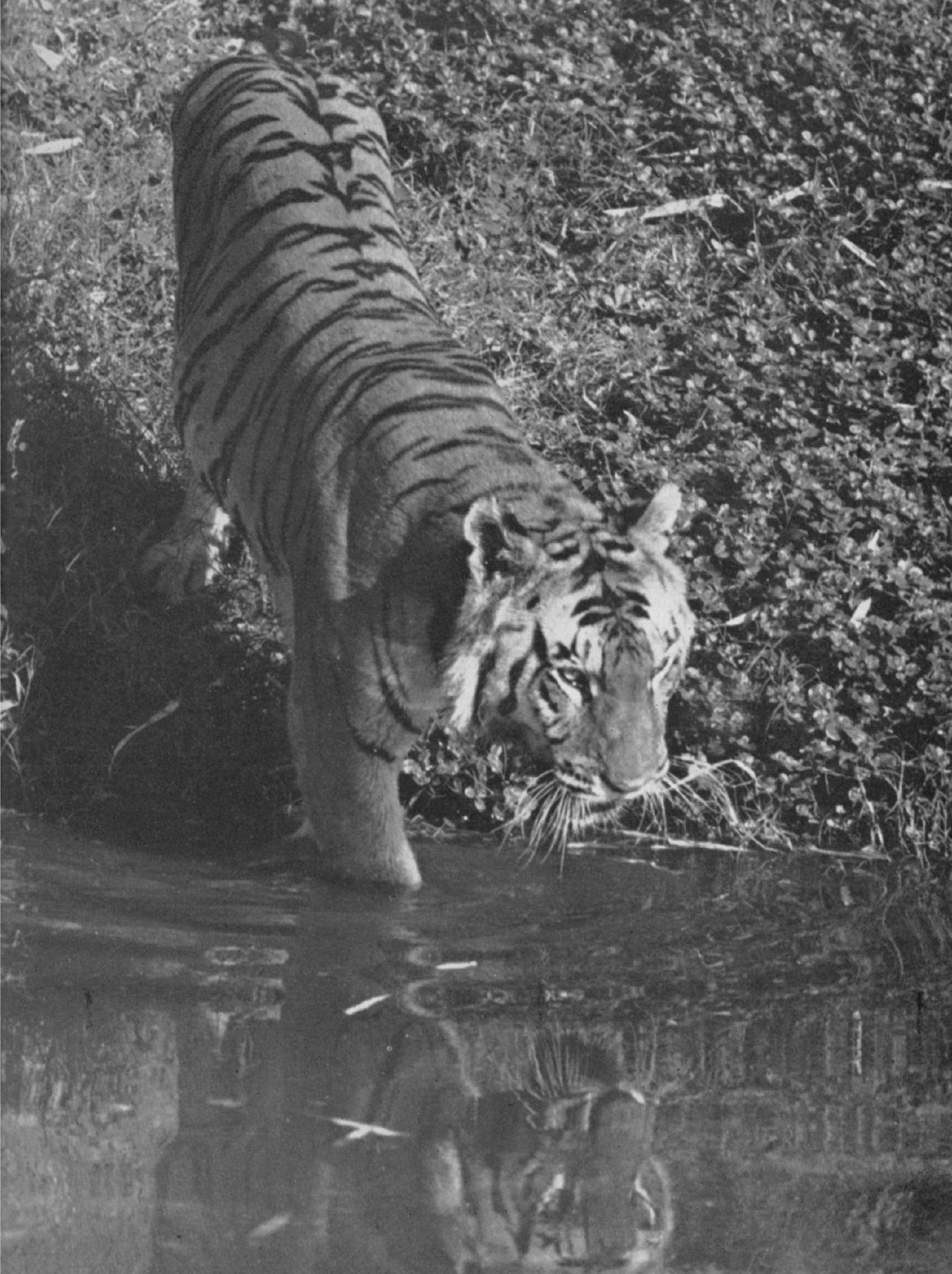

\section{Plate 5}

INDIA'S WILDLIFE. This splendid photograph of a tiger and the three pages of photographs that follow were taken by E. P. Gee, stalwart Indian conservationist and an old friend and supporter of FPS, whose death in 1968 was a serious loss to the conservation cause in India. 


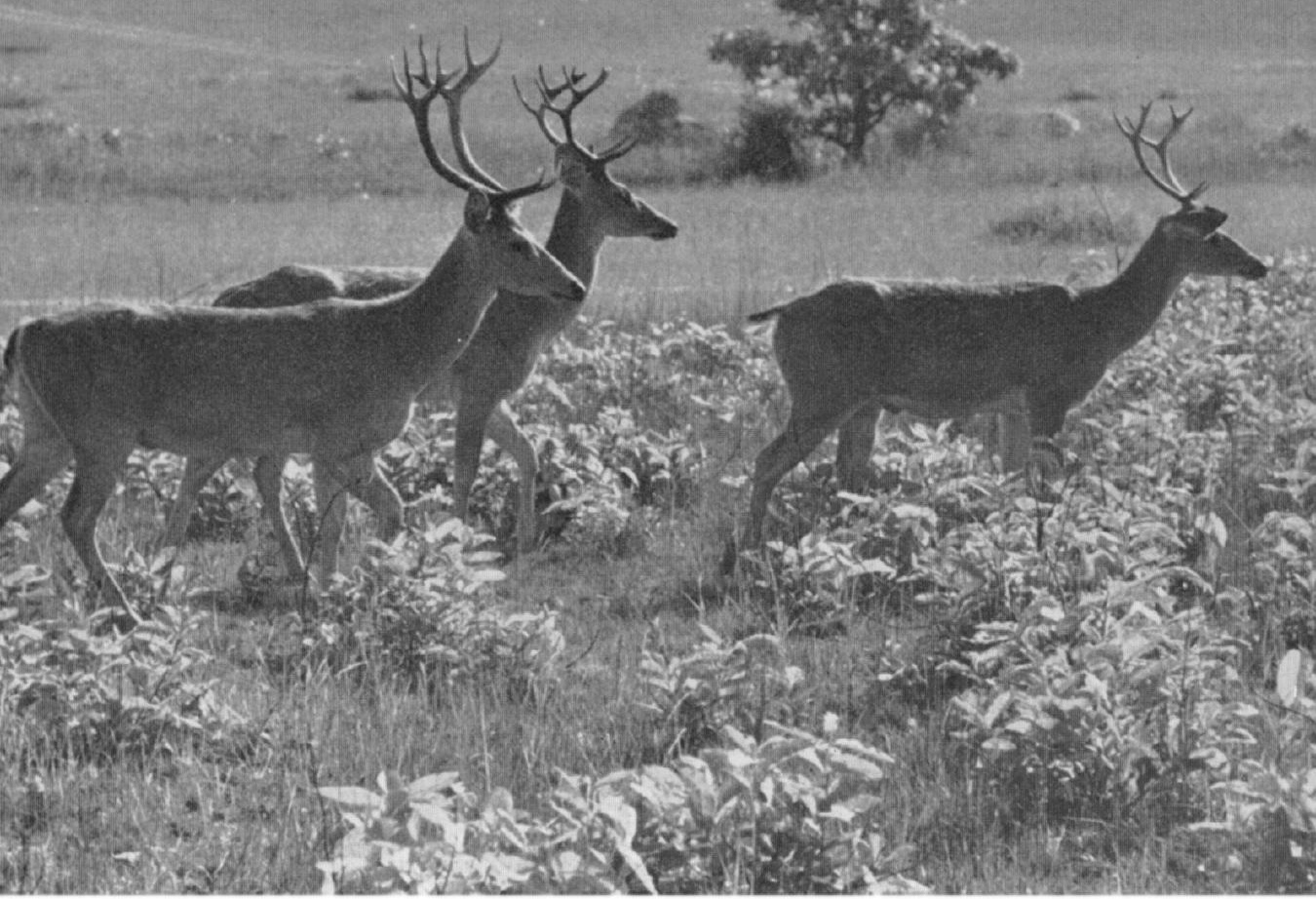

SWAMP DEER, or barasingha, in Kanha National Park

Plate 6

A STARTLED FAMILY in the Gir Sanctuary

Plate 7

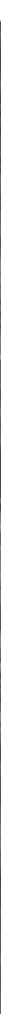




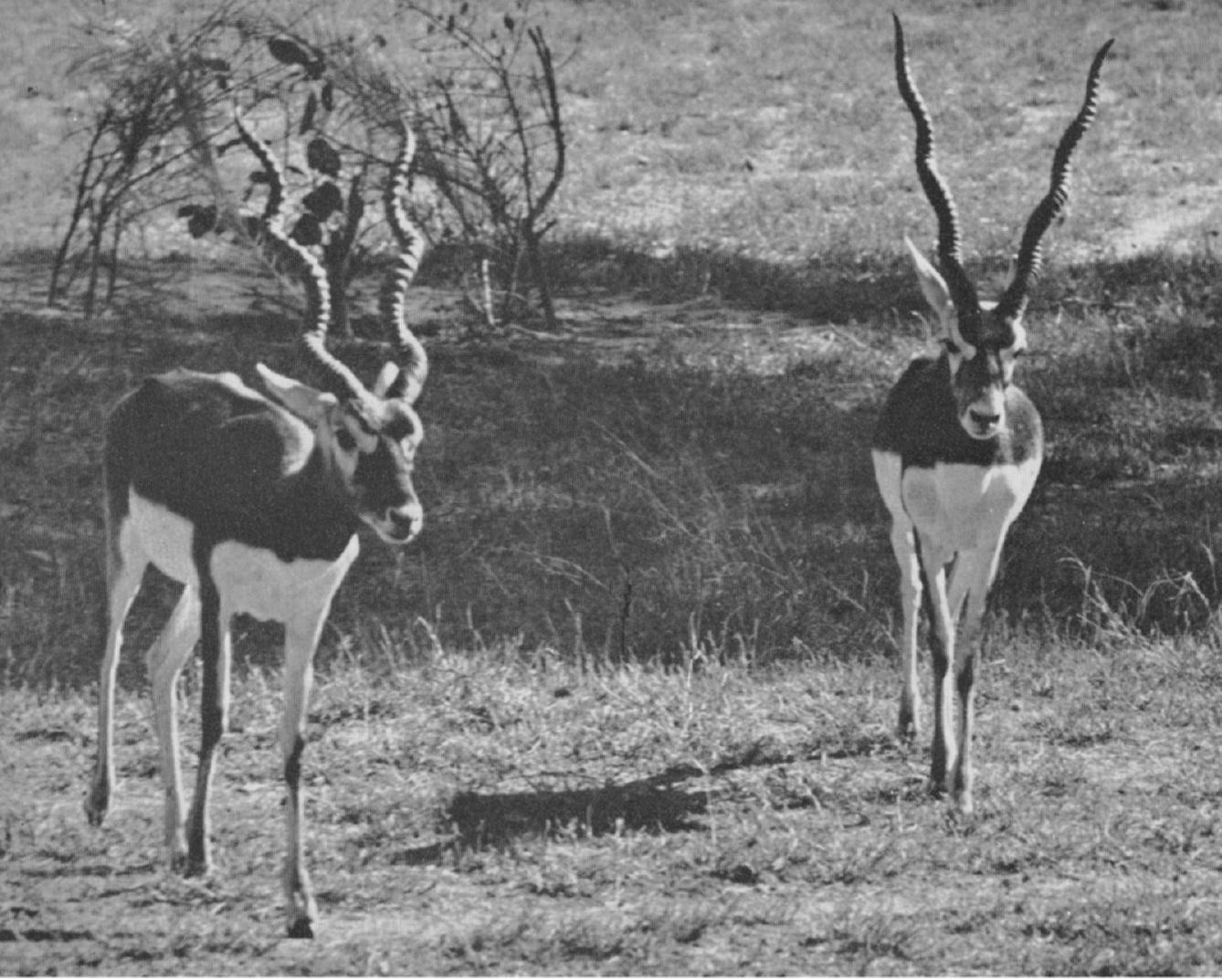

BLACKBUCK. To protect this rapidly disappearing antelope a large desert national park is needed.

Plate 8

WILD ASSES in the Little Rann of Kutch-another seriously endangered species-see page 213

Plate 9
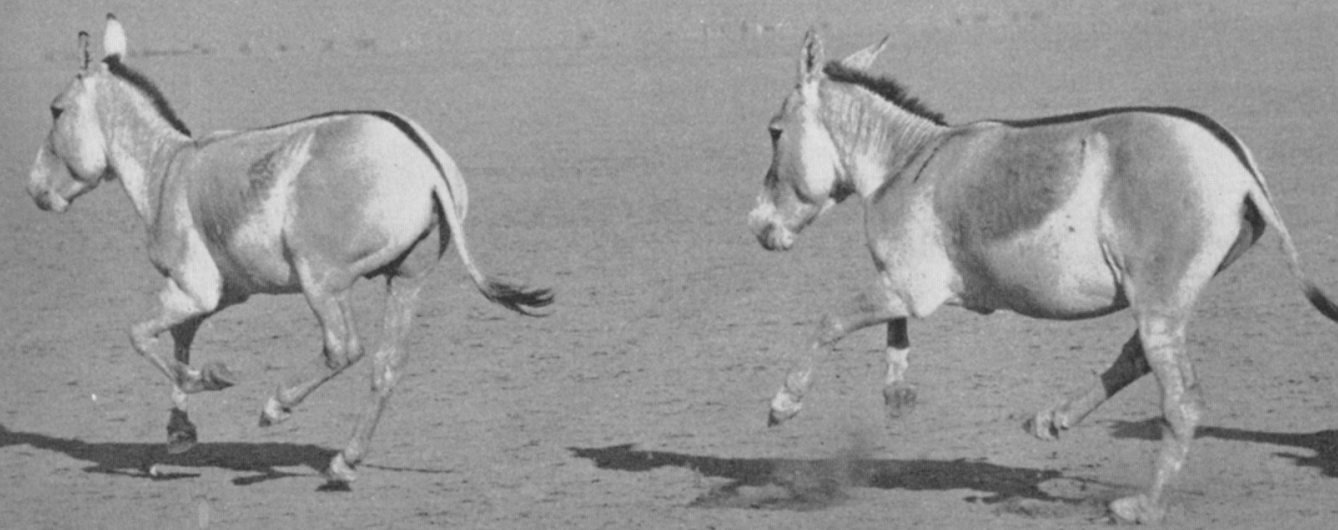


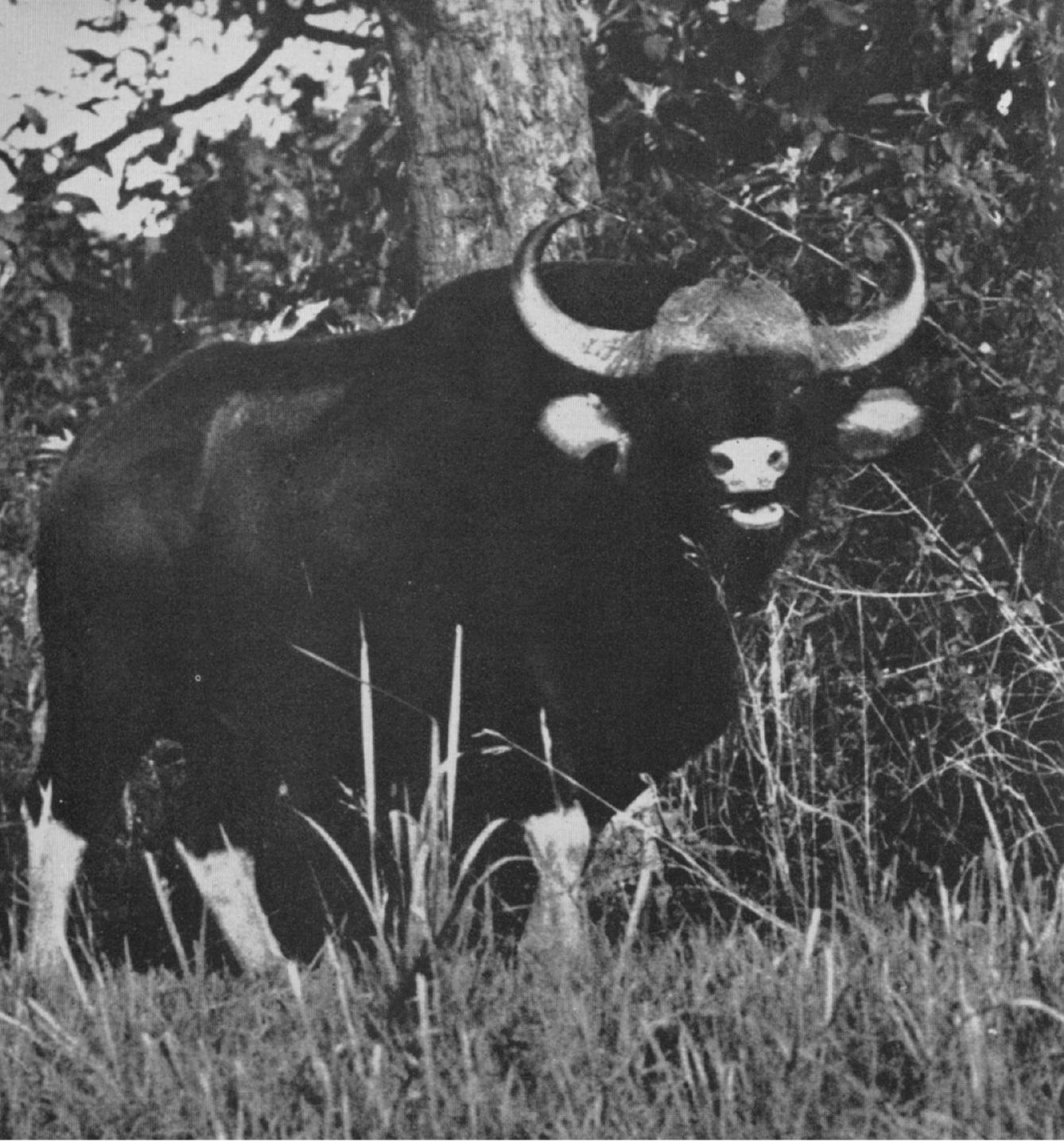

Plate 10

GAUR, the huge wild ox of India's hill forest lands which may stand over six feet at the shoulder. (The name rhymes with 'sour' according
to Gee.) 
tunately most Indian sanctuaries are not only small-few exceed 200 square miles and most are smaller-but many are grossly overgrazed and over-used. The eleven-square-mile Keoladeo Ghana sanctuary in Rajasthan-'a superlative area'-has to support some 5500 cattle and domestic buffalo.

The fourteen areas in India that qualify for the status of national parks and equivalent reserves have a total area of 2107 square miles; even if the lesser reserves are included it is only 4I20 square miles. In a country of 1.26 million square miles this is a very small proportion and emphasises the need for good management of these areas as inviolate wildlife sanctuaries, not grazing grounds for domestic stock. Most Indian forest departments do not recognise the value of wildlife, and hunting and poaching not only go unchecked, but are often practised by the government officials themselves.

The authors called for three lines of action: a realistic assessment of the grazing capacity of the sanctuaries to take account of the needs of the wildlife; control of poaching; and a reassessment of some forestry programmes, particularly the recent trend in the south to replace indigenous forest with eucalyptus.

\section{The Bengal Tiger}

Not surprisingly the animal that dominated the wildlife discussions of the Delhi conference was the tiger-'the vanishing Indian tiger', as K. S. Sankhala, Director of the Delhi Zoo, entitled his paper. This he emphasised was only a preliminary report to the full-time study on which he is embarking with the aid of a Nehru Fellowship, but his survey of the tiger situation throughout the sub-continent, including Pakistan where a small number survive in East Pakistan, suggested a tentative total of about 2500 tigers. Even with the proviso that the data is inadequate and a proper census is needed, this is a pitifully small number for this vast area and suggests a disastrous decline. It is a very far cry from the days when Gordon Cumming, for example, could shoot two tigers a day for five days and 73 in two years. Schaller and Simon in their paper suggested that $400-500$ tigers are still killed annually in India - many by villagers using poison issued by the Department of Agriculture (see ORYX, December 1967). The tiger is a very adaptable animal-it ranges throughout the sub-continent from the Himalayan foothills to the salt swamps and the rivers of the Sunderbans, in fact every type of habitat except the High Himalayas and the tropical thorn forests of the western Rajasthan desert, but the present denuded population cannot possibly stand such killing, and it is essential to control these poisons (mainly endrin and folidol) as well as the widespread hunting-'not least by government officials and military personnel who frequently shoot from jeeps at night with spotlights'.

At the open SSC (Survival Service Commission) meeting, which attracted a considerable audience who were invited to participate, the tiger provoked considerable discussion-and emotion-quite rightly according to the Chairman, Peter Scott, for where would wildlife conservation be without some emotion? Speakers fastened on the loop- 
holes in the Indian Government's ban (in 1968) on the export of tiger skins other than skins legally obtained on a government hunting licence; the most serious was the agreement to allow traders to export stocks accumulated before the ban. Shops were still openly stocking tiger (and leopard) skins, and any tourist could take one out of the country in his or her baggage. Mrs Anne Wright described a new shop in Calcutta, opened since the export ban, its shelves lined with tiger and other skins. This trade in turn encourages the poaching and poisoning, and, combined with the pressure on tiger habitat, offers little hope for a reversal of the tiger's decline without some drastic action. The SSC agreed that the tiger must go in the Red Data Book of endangered species, and the news of Mr Sankhala's Nehru Fellowship to study the ecology, behaviour and status of the tiger was warmly welcomed.

An Assembly resolution recommended to the Indian Government a moratorium on the killing of tigers, and that the tourist contribution should be shifted from licensed shooting to watching and photography, and regretted that despite the export ban on skins, tiger skins and other trophies were still openly on sale; the Government was requested to take steps to close loopholes in the enforcement of the export ban on tiger and leopard skins.

\section{The Asiatic Lion}

It is somewhat ironical that the Indian lion, with a total population of only I77 animals, all in a single forest, is nevertheless far less endangered than the tiger. 'Reasonably secure at the moment', was the verdict of Schaller and Simon. They suggested that the latest census figure of 177 lions in the Gir Forest was not necessarily evidence of a decrease; 'the accuracy of the earlier censuses (255 in 1963, 296 in 1955) is questionable, and there is no basis for assuming that the number has decreased during the past thirty years'.

An assessment of the situation presented by Paul Joslin, Canadian ecologist and PhD student, who has been studying the lions since early 1968, certainly suggests that there are factors favouring the lion-not least the development of tourism-despite the unsatisfactory conditions of the sanctuary. The most serious adverse factor affecting them is the considerable overgrazing by domestic stock in this small (500-squaremile) area: II 2 villages and hamlets, some 5000 people and 2I,000 domestic animals, with an additional 30,000 brought in during the monsoon when forage outside is scarce, and 450,000 in areas bordering the sanctuary, pose a considerable problem. Moreover, cultivation is creeping into the sanctuary along the valley floors. The inevitable result is the crowding out of the wildlife; chital, sambar, nilgai, chinkara, and four-horned antelope, the lions' natural prey, are all scarce, and the lions are driven to living on the (far from scarce) domestic stock. Joslin's preliminary analyses of lion droppings suggested that 90 per cent of the lions' prey was cattle.

But Joslin has also discovered that the lions do not always-or even usually - get their kills; most of these are taken by the Harijans (the untouchables) to whom the dead buffalo means both meat and hide and 
bones to sell. As soon as the Harijans hear about a kill they drive the lions away and appropriate it. Of 55 kills investigated Joslin found that 64 per cent had been claimed in this way; outside the sanctuary the proportion of kills appropriated was 85 per cent; the only kills not taken by Harijans were two goats which were regarded as too small to be worth having.

He also found that litters were small. Of 28 cubs recorded, the average litter size was 2.15, lower than any he had found in the literature, and mortality among cubs was high. Of 17 on which he had been able to keep some sort of continuous record, II disappeared, presumed dead.

The impact of tourism on the other hand has been markedly favourable. The great attraction is the lion 'shows', which pretty well ensure that any visitor will see lions, and during the tourist season most of the sanctuary staff are engaged in organising it. A bait (usually a young buffalo) is tied up in an area where lions have been located; when the lions have killed they are driven off and kept away from it by the armed guards until the visitors arrive, when they are allowed to start their meal - to the clicking of cameras on all sides. This provision of baits at times attracts as many as a fifth of the entire lion population to the area, and the density of lions within a ten-mile radius of the lodge was significantly higher than anywhere else in the sanctuary.

\section{Vegetation Recovers Quickly}

Some aspects of the ecological impact of the domestic stock in the Gir sanctuary were described by $\mathrm{K}$. T. B. Hodd, another PhD student working there. The long-term effect of the overgrazing, if it continues, will inevitably be to change the soil structure and composition, and, combining with the animals' trampling, make it extremely compact, with increased run-off, making regeneration more difficult. Moreover, the repeated pollarding of trees by the graziers (to provide browse for their animals and thorn fencing for the protection of themselves and the stock) has led, in one 60-square-mile area, to the eradication of certain palatable trees and their replacement with less palatable ones; within a radius of 200 yards of each settlement-and there are over a hundred-only thorny species like Acacia arabica can survive. But he has also shown, by a series of experimental exclosures, described in ORYX, September I969, the remarkable capacity of the soil to recover; after only one year his fenced-in exclosures showed a plant cover of 80-roo per cent compared with only 30 per cent in the grazed areas outside, coupled with a higher ratio of perennial grasses and some recovery of soil porosity.

The Gir Forest is scheduled to become a national park, and at first sight it would seem that the first task is to remove all the domestic stock as quickly as possible. But Joslin pointed out that the lions now depend on the stock for their prey, and that a phased withdrawal to allow the wild herbivores time to build up sufficient numbers is essential. The Chief Conservator of Forests, Shri Joshi, has a plan to establish a small inner sanctuary within the Gir, from which all cattle and 
people would be excluded, where the deer populations could build up. It is to be hoped that this sensible plan can be put into action.

\section{Discussing the Sanctuaries}

An interesting innovation in the Assembly's programme, and one which aroused considerable interest and good discussion (unfortunately axed for time-table reasons), was the pre-conference survey of a number of key reserves in India by a small group of specialists. Each group produced a report which was circulated and used as a basis for discussion. The reserves visited were: the Dachigam Sanctuary in Kashmir (for the Kashmir stag), Kanha National Park, Guindy Deer Park in Madras, Sariska and Periyar Wildlife Sanctuaries and the North Salt Lake of Calcutta. The report on the Kashmir stag (total population between $\mathrm{r} 80$ and 380 animals) made depressing reading, with grazing in the sanctuary and severe poaching making inroads in the population. However, Dr. Colin Holloway, who visited the sanctuary with Dr. George Schaller, has since returned there for a longer period of study and we hope to publish a report by him in the next issue of ORYX.

The object of the group visiting Kanha National Park, one of the best of India's sanctuaries, was to assess the scheme to capture and establish a breeding group of the seriously endangered barasingha Cervus duvauceli branderi, a subspecies of the swamp deer, now found nowhere else. Numbers have declined drastically from 3000 in 1938 to 70 in 1968, and the reasons are not entirely clear; the group suggested five possible causes-poaching, competition from other species, predation especially by tiger, changed habitat factors and disease, such as rinderpest spread by domestic cattle. The group recommended the capture of two males and four females to start the breeding group in the 74 -acre enclosure that was being erected, and that a qualified biologist should be engaged to study the barasingha both inside and outside.

In the Sariska sanctuary domestic cattle are a severe tax on the grazing, competing with the wildlife, but the visiting group felt that if present plans to exclude both human and cattle populations from the sanctuary could be implemented there would be a good case for upgrading it to the status of a national park. The conclusions of the Periyar group were that that sanctuary, too, was worthy of national park status.

\section{Recipe for Disaster in the Mountains}

One technical Assembly session was devoted to conservation of habitats and soil and water resources, with special reference to mountain regions. This produced several interesting papers, notably one by Dr. V. Z. Gulisashvili with a very clear explanation of why it was vital to preserve the high forests on mountains. Not only do these forests shelter the regions lower down from cold air masses and winds and from avalanches that start on the bare alpine zone above, but, most important, they protect and control water flow. The soils of the alpine zone tend to be impermeable and freeze hard in winter, but in the forest zone the structure of the soil, the more gradual melting of the snow in spring (the process starts earlier in the relative warmth under the trees 
and lasts longer), the filtering action of the leaf litter, and the protection from freezing given by both the litter and the tree canopy, enable the soil to absorb both the run-off from the alpine zone, the rain that falls locally and the snow melt, thus providing a reservoir of water to maintain the flow of the springs and the rivers. Clear felling of these forests destroys all these advantages (so do fire, heavy grazing and cultivation); the soil loses its litter cover, the structure changes, and the physical properties deteriorate, porosity decreases, in winter it freezes, less water is absorbed, and the result is inevitably run-off, erosion, silting, the drying-up of springs, the raising of river levels in winter and lowering of them in summer. Dr. Gulisashvili, having shown that clear felling was disastrous, went on to show that selective deforestation was little better unless certain rules were observed. Studies have shown that for the forest to retain its water-controlling capacity fewer than 50 per cent, and preferably fewer than 30 per cent of the trees could be removed, and the felling must not leave gaps larger than I5-20 metres in diameter. It has also been found that a forest of mixed-age trees performs these water-holding functions more efficiently than one of uniform age.

\section{Declaration of Purpose}

A Declaration of Purpose was agreed during the Assembly's proceedings: To urge on all governments and peoples the adoption, as a basic principle of development, the conservation and protection of long term values rather than exploitation for short term gains.

To foster sound environmental policies and to promote protection of ecosystems, human environments and habitats of wild creatures from abuse and damage.

To encourage and assist in the making of co-ordinated legislation and international conventions to govern the utilisation and treatment of soil, water, air, flora and fauna, to minimise pollution, and to protect the landscape in general and ecosystems of special interest in particular and, in summary, to urge upon all nations, action and support of those values which make life possible and worthwhile.

\section{Officers of IUCN}

The following officers were elected at the New Delhi Assembly:

Dr. Harold J. Coolidge, USA, was elected President for a second term. Five Vice-Presidents were elected: Dr. F. Fraser Darling, UK; Shri Z. Futehally, India; Professor I. McT. Cowan, Canada; Dr. C. Jouanin, France; and Professor Dr. M. F. Mörzer Bruyns, Netherlands. The President and the five Vice-Presidents together form the Executive Committee to act in the intervals between Board meetings.

Elected to the Board were Prof. I. McT. Cowan, Canada; Prof. R. Matthey, Switzerland; Prof. Dr. M. F. Mörzer Bruyns, Netherlands; Dr. M. E. D. Poore, UK; and Dr. L. M. Talbot, USA; and with effect from July I 970 : Mr. B. Dioum, Senegal; Prof. U. Hafsten, Norway; Dr.C. Jouanin, France;Dr.P.N. Neto, Brazil; and Dr. J.A.Valverde Gomez, Spain. The Chairmen of Commissions are: Survival Service, Mr. Peter Scott, UK; Education, Dr. L. K. Shaposhnikov, USSR; Ecology, Dr. J. B. Cragg, Canada; National Parks, Prof. J. P. Harroy, Belgium; Legislation, Mr. W. Burhenne, Germany; and Landscape Planning, Mr. R. J. Benthem, Netherlands. 


\section{IUCN-New Look}

The most encouraging development at the IUCN General Assembly was the prospect of adequate finance to underpin the Executive Board's programme for new and expanded activities. This was announced by the President, Dr Harold Coolidge, who was re-elected for a further term of office. In view of the changes envisaged, and following the resignation of Mr E. J. H. Berwick, who has been the Union's SecretaryGeneral for the past three years (years that have seen considerable advances in the Union's work), the new Secretary-General has been appointed also Director-General, and the team of vice-presidents has been brought up to five in order to form an Executive Committee to act in the intervals between Board meetings. The new Director-General is Dr G. Budowski, known to many IUCN members as a stalwart conservationist in the ranks of UNESCO, and he was warmly welcomed at the Delhi meeting.

IUCN is a scientific, non-governmental, international organisation; it defines its purpose as 'to initiate or promote scientifically based action that will ensure perpetuation of the living world, man's natural environment and the natural resources on which all living things depend'. Founded in 1948 , it has gradually built up a membership of 29 governments (including now the British, elected at New Delhi) and several hundred organisations as well as individuals. Its non-governmental status is important, giving it an independent position. The FPS has a special status in IUCN as a recognised international organisation, and has always had a close relationship. Both the Hon. Secretary and the Editor of ORYX are members of the SSC (Survival Service Commission), one of IUCN's six commissions, of which Peter Scott, Chairman of FPS, is Chairman. Dr Fraser Darling, a Council member of FPS, is a Vice-President of IUCN.

\section{The Commissions}

The IUCN programme envisages continuing the commission structure-Survival Service, Ecology, National Parks, Education, Legislation and Landscape Planning-which enables the Union to draw on a large number of the world's experts in the various fields, and improving its efficacy and efficiency by appointing an executive officer for each commission to work at headquarters in Morges; improving the information centre at Morges; participating more actively with technical assistance organisations such as FAO and UNESCO; promoting conservation in large development programmes, especially those promoted by the UNDP (United Nations Development Programme) and the World Bank (it is still not unknown for large projects to be initiated with only the sketchiest attention to ecological considerations); and forming Project Groups to handle particular conservation problems-the examples cited are a Kouprey Project Group to make plans for saving this highly endangered Cambodian mammal, and a Javan Rhino Group to co-ordinate the work already started by WWF, FPS, Basel Patronage Committee and the National Biological Institute at Bogor, in Indonesia. 
The programme envisaged for the SSC, which is the commission concerned with endangered species, largely confirms the plans already in hand: to continue servicing the Red Data books already published (on endangered mammals, birds and fish); publish new volumes on amphibia and reptiles (already under way), molluscs, and plants (angiosperms and gymnosperms), and to initiate volumes on insects, pteridophytes and bryophytes; to promote closer relations with the Ecology and National Parks Commissions; to promote awareness of threatened species among the governments in the countries where they are found, and in the science departments of the world's universities, and encourage their participation in the study and management of endangered species; to concentrate efforts on species such as the marine turtles, whose conservation demands international action; to continue efforts to promote conservation through zoos and botanical gardens; and to be ready to act in emergencies.

Hitherto the SSC has been the only Commission to have a full-time secretary, and this coupled with regular meetings (at least three times a year) has enabled the SSC to become one of the most effective of the Commissions. By keeping the pot constantly stirred it has undoubtedly proved an influence to be reckoned with and has chalked up several successes. The publication of the Red Data books (brain-child of the Chairman) has probably done more to popularise and publicise the task of saving endangered species than almost any other single event. FPS works closely with SSC and has more than once been able to step in, in really urgent and desperate cases, with a timely contribution from the FPS/WWF Revolving Fund.

\section{WWF Report - How Half a Million was Spent}

It is heartening indeed to read, in the excellently produced and illustrated World Wildlife Fund Yearbook 1968, edited by Fritz Vollmar, that the Fund was able to spend $£ 575,335$ on 90 projects in that one year. Individual grants ranged from $f g$ to the Dombes Nature Reserve in France to $£ 150,853$ for the New Jersey Wetlands in the USA, and include the $\{30,732$ final payment for the Coto Doñana in Spain-a splendid achievement this, crowned by General Franco's decree, on October I6, 1969, declaring Coto Doñana a national park. (In all WWF has paid $f, 150,600$ of the total cost of $£ 222,600$; the Spanish government paid the rest.) The projects are described by individuals involved in them, and their accounts give much useful and interesting background information. Projects in which FPS was involved-by making partly repayable loans through the Revolving Fund-include dugongs in Ceylon, the tamaraw in the Philippines, game-guard training in Ghana, the reintroduction of Swinhoe's pheasant in Taiwan and anti-poaching equipment in the Uganda national parks.

But while it is pleasing that over half a million pounds could be spent in one year, it is only too true that it is far from enough. In an introduction to the Yearbook, an American trustee, Mr Arthur M. Godfrey, points out that, in that same year, foundations in the USA made grants totalling 753 million dollars: $308 \mathrm{~m}$. for education, $23 \mathrm{~m}$. for religion, $74 \mathrm{~m}$. for welfare, and so on; and for conservation of all kinds- 3 million, less than half of one per cent. And the same proportions probably apply elsewhere. 